\title{
Notas Científicas \\ Esterilização química de meio de cultura no cultivo in vitro de antúrio
}

\author{
Jean Carlos Cardoso(1) \\ ${ }^{(1)}$ Van Vliet Gérberas e Antúrios, Laboratório de Biotecnologia Vegetal, Caixa Postal 170, CEP 13825-970 Holambra, SP. \\ E-mail: jeancardosoctv@gmail.com
}

\begin{abstract}
Resumo - O objetivo deste trabalho foi avaliar o uso do dióxido de cloro ou do ácido peracético na esterilização química de meio de cultura e no desenvolvimento de mudas de antúrio (Anthurium andraeanum) cultivadas in vitro. Os tratamentos consistiram de dióxido de cloro e ácido peracético a 0,005 e $0,010 \%$. Foi utilizado como controle o meio autoclavado. As mudas de antúrio foram cultivadas em meio de alongamento e enraizamento MS, com a concentração de nutrientes reduzida pela metade. $O$ ácido peracético, nas concentrações utilizadas, não foi efetivo na esterilização do meio de cultura; o dióxido de cloro, porém, teve eficiência de $100 \%$, sem causar fitotoxicidade às mudas.
\end{abstract}

Termos para indexação: Anthurium andraeanum, ácido peracético, dióxido de cloro, esterilização, micropropagação.

\section{Chemical sterilization of culture medium for anthurium in vitro culture}

Abstract - The objective of this study was to evaluate the use of chlorine dioxide or of peracetic acid in the chemical sterilization of culture medium and in the development of anthurium (Anthurium andraeanum) plantlets cultured in vitro. Treatments consisted of chlorine dioxide and peracetic acid at 0.005 and $0.010 \%$. The autoclaved medium was used as control. The anthurium plantlets were grown in elongation and rooting MS medium with the concentration of macronutrients reduced by half. The peracetic acid, in the concentrations used, was not effective in the sterilization of culture medium. The chlorine dioxide had $100 \%$ efficiency in the sterilization of culture medium and caused no phytotoxicity to plantlets.

Index terms: Anthurium andraeanum, peracetic acid, chlorine dioxide, sterilization, micropropagation.

O cultivo de plantas in vitro envolve procedimentos que demandam tempo e oneram os custos das mudas produzidas por micropropagação. O preparo do meio de cultura para o cultivo das plantas envolve, basicamente, o processo de preparo em si e a autoclavagem. A autoclavagem é um procedimento que utiliza altas temperaturas $\left(121^{\circ} \mathrm{C}\right)$ e pressão $\left(1 \mathrm{kgf} \mathrm{cm}^{-2}\right)$ por períodos de 15 a $30 \mathrm{~min}$, para eliminação de microrganismos no meio de cultura e no recipiente de cultivo das plantas (Torres et al., 1998). Além de elevar os custos de produção das mudas micropropagadas pelo alto consumo energético das autoclaves (Teixeira et al., 2005b), a autoclavagem também reduz o rendimento de produção de meios de cultura no laboratório, em razão do tempo demandado para esse procedimento.

Técnicasalternativasàautoclavagem têmsidotestadas em diferentes trabalhos, em procedimentos físicos, como o micro-ondas (Teixeira et al., 2005a, 2005b), e químicos, com uso do hipoclorito de sódio (Teixeira et al., 2006, 2008) e do peróxido de hidrogênio (Yanagawa et al., 1995). Essas alternativas têm tido sucesso na desinfestação de meios de cultura, porém têm causado problemas de fitotoxicidade, em geral pelos produtos químicos utilizados na esterilização ou por dificuldades no uso dessas técnicas.

Outro produto utilizado na esterilização química de meios de cultura é o PPM ("plant preservative mixture"), porém, a maioria dos protocolos de cultura de tecidos restringe seu uso em associação à autoclavagem, apenas para prevenir contaminações após o processo (Erig \& Schuch, 2002; Jiménez et al., 2006).

O ácido peracético possui ação viricida, bactericida e fungicida e é utilizado como desinfetante em diferentes segmentos industriais (Peróxidos do Brasil Ltda, 2009).

Segundo Aquastel (2009), o dióxido de cloro é considerado um potente desinfetante e agente oxidante 
e contém cloro na molécula, podendo atuar como bactericida e fungicida. Entre as vantagens do uso de dióxido de cloro está a ausência de reatividade com amônia, o que evita a formação de cloraminas, tóxicas a animais principalmente. $\mathrm{O}$ dióxido de cloro é considerado estável em soluções numa faixa de $\mathrm{pH}$ entre 3 e 9, com maior efetividade como agente desinfetante em $\mathrm{pH}$ próximo à neutralidade (Junli et al., 1997).

O objetivo deste trabalho foi avaliar o uso do dióxido de cloro ou do ácido peracético na esterilização química do meio de cultura e no desenvolvimento de mudas de antúrio cultivadas in vitro.

O experimento foi conduzido no laboratório de biotecnologia vegetal da empresa Van Vliet Gérberas e Antúrios, em Holambra, SP, em 2009.

O meio de cultura de alongamento e enraizamento utilizado foi o MS (Murashige \& Skoog, 1962), com concentração de macronutrientes reduzida pela metade, suplementado com $20 \mathrm{~g} \mathrm{~L}^{-1}$ de sacarose e $0,1 \mathrm{~g} \mathrm{~L}^{-1}$ de mioinositol, sem a adição de reguladores vegetais. $\mathrm{O}$ pH foi ajustado para 5,8 .

Foi utilizado, como controle, o processo de autoclavagem para esterilização física. Utilizou-se autoclave vertical de $100 \mathrm{~L}$, em que os frascos de vidro com o meio de cultura foram autoclavados a $121^{\circ} \mathrm{C}$ e pressão de $1 \mathrm{kgf} \mathrm{cm}^{-2}$ por $25 \mathrm{~min}$. Após a autoclavagem, os frascos com o meio de cultura foram levados para sala de crescimento.

Os tratamentos de esterilização química consistiram do uso de dois produtos comerciais: o Tecsa-Clor, que tem como ingrediente ativo o dióxido de cloro estabilizado (5\%) na forma líquida; e o Proxitane, que tem o ácido peracético $(5 \%)$ como seu principal ingrediente ativo. Ambos os produtos têm ação desinfetante e têm sido utilizados na agricultura para tratamentos pós-colheita de frutas e hortaliças. Foram testadas as concentrações de 0,005 e 0,01\% de dióxido de cloro e de ácido peracético, com base nas concentrações recomendadas pelos fabricantes para outras aplicações e em concentrações eficientes obtidas com tratamentos pós-colheita (Srebernich, 2007).

Os produtos químicos dióxido de cloro ou ácido peracético foram adicionados ao meio de cultura MS após a adição de todos os componentes, com exceção do Gelrite, e antes do ajuste do pH do meio. Após a adição dos agentes esterilizantes, seguiu-se o ajuste do $\mathrm{pH}$ e a adição de $1,6 \mathrm{~g} \mathrm{~L}^{-1}$ de Gelrite ao meio que, em seguida, foi aquecido até o ponto de fervura, para dissolução e gelificação do meio de cultura. Ainda quente, o meio de cultura foi redistribuído em frascos de vidro de $200 \mathrm{~mL}$ previamente lavados com água e detergente neutro, tendo-se utilizado cerca de $30 \mathrm{~mL}$ de meio de cultura por frasco. Os meios de cultura e os frascos de vidro utilizados não foram autoclavados e foram armazenados em sala de crescimento logo após a gelificação.

Como material vegetal, foram utilizadas mudas de antúrio cv. Red Star em final de fase de multiplicação in vitro, com cerca de $1 \mathrm{~cm}$ de altura, duas folhas e sem raízes. Os meios foram verificados quanto à possível contaminação e, após sete dias de seu preparo, as mudas foram inseridas neles.

$\mathrm{O}$ experimento foi conduzido em delineamento de blocos inteiramente casualizados, com cinco tratamentos: dióxido de cloro a 0,005 e $0,01 \%$; ácido peracético a 0,005 e $0,01 \%$; e o controle (meio de cultura autoclavado). Foram utilizadas 10 repetições (frascos), com 12 plantas cada, no total de 120 plantas por tratamento.

As plantas foram cultivadas em sala de crescimento a $26 \pm 1^{\circ} \mathrm{C}$ e umidade relativa de $60 \pm 5 \%$, durante 90 dias. A luminosidade foi fornecida por lâmpadas frias brancas, com densidade de fluxo de fótons de $40 \mu \mathrm{mol} \mathrm{m}{ }^{-2} \mathrm{~s}^{-1}$ e 16 horas de fotoperíodo.

Para avaliação da eficiência dos métodos de esterilização, foram analisados o grau de solidificação dos meios de cultura aos sete dias e a percentagem de frascos contaminados com bactérias e fungos, nos tratamentos utilizados, aos 90 dias de cultivo. Para verificação de efeitos fitotóxicos dos produtos químicos, foram avaliados: altura, massa de matéria fresca, diâmetro de folhas, número de folhas e de raízes emitidas, em cada tratamento, aos 90 dias de cultivo. Os tratamentos com cada produto foram submetidos a análise de variância e comparados ao controle (autoclavagem) pelo teste de Tukey, a 5\% de probabilidade.

Nos tratamentos com o ácido peracético como agente da esterilização química, os meios de cultura não solidificaram corretamente e apresentaram consistência de semissólida a líquida, o que dificultou a disposição correta das mudas. Além disso, após 14 dias de cultivo, iniciaram-se as contaminações com fungos e bactérias no meio de cultura e, ao final de 21 dias, todos os frascos estavam com intensa 
contaminação fúngica. Esse fato não possibilitou a avaliação das mudas de antúrios cultivadas nesse meio, aos 90 dias, em razão da morte das plantas. O ácido peracético é instável em altas temperaturas (Peróxidos do Brasil Ltda, 2009) e pode ter sido degradado após o aquecimento utilizado para dissolver o Gelrite e solidificar o meio de cultura, o que ocasionou as contaminações.

Entretanto, o uso do dióxido de cloro a 0,005 e 0,01\% foi eficiente na esterilização dos meios e não possibilitou a contaminação fúngica ou bacteriana durante os 90 dias de cultivo. O meio de cultura manteve consistência semissólida típica e muito semelhante à dos meios de cultura autoclavados (controle), durante o período de cultivo, nas duas concentrações de dióxido de cloro utilizadas. O uso do método da autoclavagem também apresentou eficiência na esterilização dos meios, e não houve contaminações fúngicas ou bacterianas após 90 dias de cultivo. O dióxido de cloro age, na maioria das vezes, por meio de um mecanismo de transferência de elétrons, penetrando e desidratando a membrana celular e, por último, oxidando os componentes intracelulares de microrganismos gram-negativos e gram-positivos, porém sem os efeitos negativos de fitotoxicidade que os demais compostos clorados, como os hipocloritos, apresentam. A natureza apolar do dióxido de cloro auxilia na ação sanitizante e esporicida, em razão da maior solubilidade em moléculas orgânicas complexas como as presentes na maioria dos vírus e bactérias (Srebernich, 2007).

Teixeira et al. (2006) obtiveram sucesso na esterilização de meio de cultura líquido, para multiplicação de abacaxizeiro, com uso de $\mathrm{NaOCl}$ (hipoclorito de sódio) como agente químico de esterilização. Em trabalho realizado com cultivo in vitro de Eucalyptus pellita, em meio esterilizado com $\mathrm{NaOCl}$, os autores não observaram problemas de desenvolvimento das plantas até a concentração de $0,007 \%$, e obtiveram $100 \%$ de esterilização dos meios de cultura a $0,005 \%$ de $\mathrm{NaOCl}$ (Teixeira et al., 2008). Segundo os autores, o sucesso da esterilização química com o $\mathrm{NaOCl}$ deve-se não apenas à adição do produto ao meio de cultura, mas também ao procedimento de sanitização das vidrarias com $\mathrm{NaOCl}$ previamente à distribuição do meio nos recipientes de cultivo, já que Yanagawa et al. (1995) observaram problemas de contaminação dos meios com o uso do $\mathrm{NaOCl}$ e ausência de sanitização da vidraria.

Em relação ao desenvolvimento da parte aérea de mudas de antúrio, não ocorreram efeitos fitotóxicos aparentes, tais como escurecimento ou sinais de oxidação, em nenhuma das concentrações utilizadas de dióxido de cloro. Efeitos reguladores do desenvolvimento foram observados, pois houve aumento no número e diâmetro de folhas nos tratamentos com dióxido de cloro a $0,005 \%$ em relação ao meio autoclavado (Tabela 1). A massa de matéria fresca total se manteve estável nos tratamentos químicos e no meio autoclavado. Observou-se redução do tamanho das mudas cultivadas, obtidas em meio com esterilização química, em relação ao meio autoclavado. Não foram observados danos às raízes, como escurecimento ou sinais de oxidação que poderiam ser causados pelo dióxido de cloro, nas concentrações utilizadas, e as raízes se mantiveram brancas e pilosas, características da espécie.

A técnica de esterilização química com dióxido de cloro foi efetiva até 90 dias de cultivo, tempo que abrange o ciclo de cultivo in vitro da maioria das espécies. Além disso, essa técnica apresentou resultados positivos em meio de cultura (MS 1/2) e em frascos de cultivo de $200 \mathrm{~mL}$, utilizados em larga escala em laboratórios comerciais. Os frascos foram lavados apenas com água e detergente neutro, sem o uso de qualquer agente de esterilização além daquele adicionado ao meio, o que acelerou o processo de preparo de meios de cultura.

O uso da esterilização química é uma alternativa adequada ao sistema de autoclavagem, e o dióxido de cloro a $0,005 \%$ pode ser empregado para o processo de esterilização com eficiência semelhante à da autoclavagem. Não houve problemas de fitotoxicidade,

Tabela 1. Desenvolvimento de mudas de antúrio (Anthurium andraeanum) em meios de cultura autoclavados e com uso da esterilização química com dióxido de cloro $^{(1)}$.

\begin{tabular}{|c|c|c|c|c|c|}
\hline Tratamento & Altura $(\mathrm{cm})$ & $\mathrm{N}^{\mathrm{o}}$ de folhas & Diâmetro folhas (cm) & $\mathrm{N}^{o}$ de raízes & Massa de matéria fresca $(\mathrm{g})$ \\
\hline Autoclavado & $2,59 \mathrm{a}$ & $4,57 b$ & $0,82 b$ & $3,40 \mathrm{a}$ & $1,70 \mathrm{a}$ \\
\hline $\mathrm{ClO}_{2}(0,005 \%)$ & $2,25 b$ & $5,10 \mathrm{a}$ & $0,92 \mathrm{a}$ & $3,47 \mathrm{a}$ & $1,72 \mathrm{a}$ \\
\hline $\mathrm{ClO}_{2}(0,010 \%)$ & $2,09 \mathrm{~b}$ & $4,70 \mathrm{ab}$ & $0,83 \mathrm{ab}$ & $3,80 \mathrm{a}$ & $1,75 \mathrm{a}$ \\
\hline
\end{tabular}

${ }^{(1)}$ Médias seguidas por letras iguais não diferem entre si pelo teste de Tukey, a $5 \%$ de probabilidade. 
e a qualidade das mudas de antúrio cultivadas em meio com dióxido de cloro foi mantida em comparação àquelas cultivadas em meio autoclavado.

\section{Referências}

AQUASTEL. Propriedades dos desinfetantes da água. Disponível em: $<$ http://www.aquastel.com.br/index1.htm $>$. Acesso em: 11 jan. 2009.

ERIG, A.C.; SCHUCH, M.W. Multiplicação in vitro do porta-enxerto de macieira cv. Marubakaido: efeito da orientação do explante no meio de cultura. Revista Brasileira de Fruticultura, v.24, p.293-295, 2002.

JIMÉNEZ, V.M.; CASTILLO, J.; TAVARES, E.; GUEVARA, E.; MONTIEL, M. In vitro propagation of the neotropical giant bamboo, Guadua angustifolia Kunth, through axillary shoot proliferation. Plant Cell, Tissue and Organ Culture, v.86, p.389-395, 2006.

JUNLI, H.; LI, W.; NANQUI, R.; FANG, M.; JULI. Disinfection effect of chlorine dioxide on bacteria in water. Water Research, v.31, p.607-613, 1997.

MURASHIGE, T.; SKOOG, F. A revised medium for rapid growth and bio assays with tobacco tissue cultures. Physiologia Plantarum, v.15, p.473-497, 1962.

PERÓXIDOS DO BRASIL LTDA. Proxitane ${ }^{\circ}$ 0510: descrição do produto. Disponível em: <http://www.peroxidos.com.br/product/ description/0,0,0695,00.html>. Acesso em: 20 fev. 2009.
SREBERNICH, S.M. Utilização do dióxido de cloro e do ácido peracético como substitutos do hipoclorito de sódio na sanitização do cheiro-verde minimamente processado. Ciência e Tecnologia de Alimentos, v.27, p.787-792, 2007.

TEIXEIRA, S.L.; RIBEIRO, J.M.; TEIXEIRA, M.T. Influence of $\mathrm{NaClO}$ on nutrient medium sterilization and on pineapple (Ananas comosus cv. Smooth cayenne) behavior. Plant Cell, Tissue and Organ Culture, v.86, p.375-378, 2006.

TEIXEIRA, S.L.; RIBEIRO, J.M.; TEIXEIRA, M.T. Utilização de hipoclorito de sódio na esterilização de meio de cultura para multiplicação in vitro de Eucalyptus pellita L. Ciência Florestal, v.18, p.185-191, 2008.

TEIXEIRA, S.L.; SOUZA, R.T. de S.; TEIXEIRA, M.T. Esterilização de meios nutritivos para cultura de tecidos vegetais em forno de microondas. Revista Ceres, v.52, p.499-507, 2005a.

TEIXEIRA, S.L.; TEIXEIRA, M.T.; CAMPANATI, M.; ALMEIDA, R.F. de. Cultura de tecidos vegetais, pela combinação de esterilizantes químicos e forno de microondas. Revista Ceres, v.52, p.343-349, 2005 b.

TORRES, A.C.; CALDAS, L.S.; BUSO, J.A. Cultura de tecidos e transformação genética de plantas. Brasília: Embrapa-SPI: Embrapa-CNPH, 1998. v.1, 509p.

YANAGAWA, T.; NAGAI, M.; OGINO, T.; MAEGUCHI, R. Application of disinfectants to orchid seeds, plantlets and media as a means to prevent in vitro contamination. Lyndleyana, v.10, p.33-36, 1995.

Recebido em 1으 de março de 2009 e aprovado em 3 de julho de 2009 